\title{
A New Logarithmic Normalization Method in Games Theory
}

\author{
Edmundas Kazimieras ZAVADSKAS, Zenonas TURSKIS \\ Vilnius Gediminas Technical University \\ Sauletekio al. 11, LT-10223 Vilnius, Lithuania \\ e-mail: edmundas.zavadskas@adm.vgtu.lt
}

Received: April 2007

\begin{abstract}
Multi-criteria decision making is used in many areas of human activities. Each alternative in multi-criteria decision making problem can be described by a set of criteria. Criteria can be qualitative and quantitative. They usually have different units of measurement and different optimization direction. The normalization aims at obtaining comparable scales of criteria values. The normalization of criteria values is not always needed, but it may be essential. In the new program LEVI 3.1 the following normalization methods are possible: vector, linear scale, non-linear and new logarithmic techniques. Logarithmic normalization has never been used before. The present research is focused on introducing a new logarithmic method for decision making matrix normalization.
\end{abstract}

Keywords: games theory, multiple criteria, decision matrix, logarithmic normalization, decision making in engineering, case study.

\section{Introduction}

A review of standard decisions made in engineering, management and economy has shown that the deficiency of information is often ignored. Experts not always make use of the appropriate initial data. The values applied are often exaggerated. Poor quality models are used which, if required, are slightly corrected based of practical experience. However, the actual situation is not properly reflected and possible effects of external actions are not known. A decision is often made by comparing costs and benefits of the available alternative under various environmental conditions.

The evaluation of all possible actions is not always sufficient. Each action may lead to several, sometimes conflicting results. As the actual result is not known, the criteria taking into consideration all possible results are needed. Therefore, multi-criteria decision making becomes extremely important. An alternative in multi-criteria evaluation is usually described by quantitative and qualitative criteria. These criteria have different units of measurement. Normalization is aimed at obtaining the comparable scales of the criteria values. Different techniques of criteria value normalization are used. Normalization of the criteria values is not always necessary.

The impact of the decision matrix normalization methods on the decision results has been investigated by many authors (Weitendorf, 1976; Hwang and Yoon, 1981; Peld- 
schus et al., 1983, 2002; Peldschus, 1986, 2001, 2007; Peldschus and Zavadskas, 1997; Dejus, 2002; Körth, 1969; Stopp, 1975; Jüttler, 1966; Migilinskas, 2003; Migilinskas and Ustinovichius, 2007; Kaklauskas et al., 2007; Kalibatas et al., 2007; Turskis et al., 2006; Zagorskas and Turskis, 2006; Ginevicius and Podvezko, 2007; Noorul Haq and Kannan, 2007; Antucheviciene et al., 2006; Brauers and Zavadskas, 2006; Brauers et al., 2007; Brauers, 2007a, 2007b; Viteikienè, 2006; Viteikienė and Zavadskas, 2007; Hovanov, 1996; Cloquell and Santamarina, 2001; Zavadskas, 1987; Zavadskas et al., 1994, 2002, 2003, 2004, 2006, 2007a, 2007b; Ustinovichius, 2001, 2004, 2007; Ustinovichius and Zavadskas, 2004; Ustinovichius et al., 2007; Vaidogas and Zavadskas, 2007; Vaidogas et al., 2007). The authors of many well-known programs chose one particular problem solution method or approach to decision-making matrix normalization. There are still no rules determining the application of multi-criteria evaluation methods and interpretation of the results obtained.

Vilnius Gediminas Technical University (VGTU) and Leipzig University of Applied Sciences (HTKW) have been investigating the application of games theory principles to civil engineering technology and management problems for more than 20 years (Peldschus et al., 1983, 2002; Peldschus, 2001, 2007; Peldschus and Zavadskas, 1997; Zavadskas, 1987; Zavadskas and Kaklauskas, 2007). The program LEVI 3.0 was a result of the co-operation between VGTU and HTKW. All calculations were made with LEVI 3.0 (Zavadskas et al., 2002, 2003, 2004; Peldschus et al., 2002; Peldschus, 2007). The program LEVI 3.1 was created for evaluating various processes in economics, engineering and management.

In the new program LEVI 3.1 (Fig. 1), a new logarithmic normalization method is implemented. This new software allows us to find a solution under the conditions of risk and uncertainty and to compare the results by applying different methods.
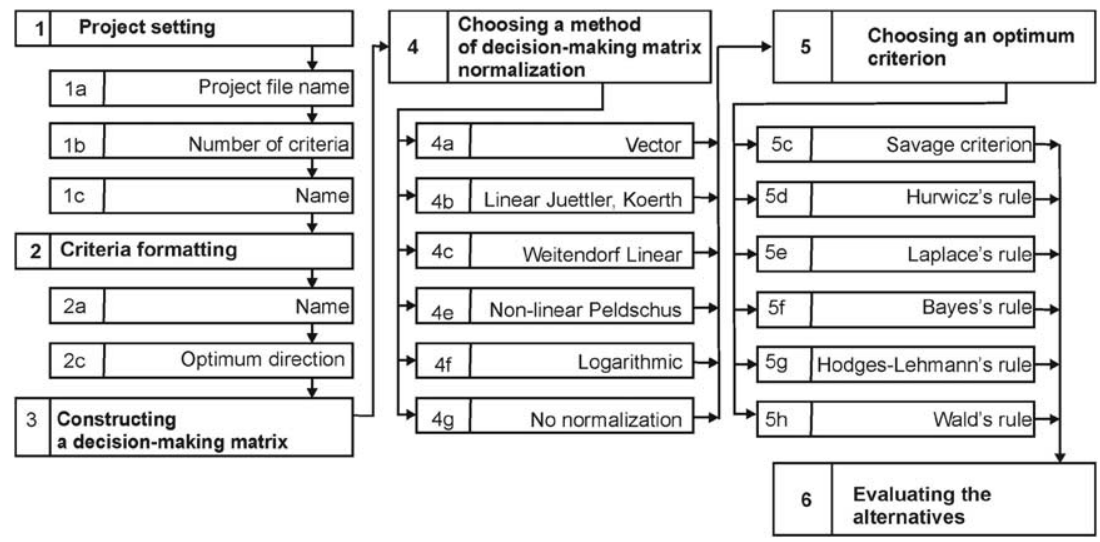

Fig. 1. Block-diagram of choosing the best alternative in LEVI 3.1 program. 


\section{Structure and Methodology of the Program LEVI 3.1}

In the program LEVI 3.1, the games theory of the discrete optimization problem solution is used. Any problem to be solved is represented by a matrix, containing the alternatives (rows) and the criteria (columns). Usually, the criteria have different dimensions. In order to avoid the difficulties caused by different dimensions of the criteria, the ratio to the optimal value is used. There are various theories describing the ratio to the optimal value. However, the values are mapped either on the interval $[0 ; 1]$ or the interval $[0 ; \infty]$ by applying the normalization of a decision-making matrix. In the program LEVI 3.1, only the widely known and logarithmic normalization methods are used (Table 1).

When the normalization is completed, it is possible to evaluate the criteria with weighting factors $0 \prec q_{j} \prec 1$. The sum of the weighting factors should be equal to 1 . Only well-founded weighting factors should be used because weighting factors influencing the solution are always subjective. Using the Games Theory (von Neumann and Morgenstern, 1943), the two-sided test aims at finding the equilibrium as a result of the rational behaviour of two parties having the opposite interests or searching for the equilibrium in a game against nature.

Table 1

Normalization methods in the program LEVI 3.1

\begin{tabular}{|c|c|c|c|c|}
\hline & $\begin{array}{l}\text { Normalization } \\
\text { method (NM) }\end{array}$ & Preferable $\max a_{i j}$ & Preferable $\min a_{i j}$ & Notes \\
\hline 1 & $\begin{array}{l}\text { Vector (VE) } \\
\text { normalization } \\
\text { (Van Deft and } \\
\text { Nijkamp, 1977) }\end{array}$ & $b_{i j}=\frac{a_{i j}}{\sqrt{\sum_{i=1}^{m} a_{i j}^{2}}}$ & $b_{i j}=1-\frac{a_{i j}}{\sqrt{\sum_{i=1}^{m} a_{i j}^{2}}}$ & $\begin{array}{l}\text { The ratio of the } \\
\text { values remains } \\
\text { constant for this type } \\
\text { of normalization in } \\
\text { the interval }[0 ; 1] .\end{array}$ \\
\hline 2 & $\begin{array}{l}\text { Weitendorf's } \\
(1976) \text { linear } \\
\text { (WL) } \\
\text { normalization }\end{array}$ & $b_{i j}=\frac{a_{i j}-\min _{i} a_{i j}}{\max _{i} a_{i j}-\min _{i} a_{i j}}$ & $b_{i j}=\frac{\max _{i} a_{i j}-a_{i j}}{\max _{i} a_{i j}-\min _{i} a_{i j}}$ & $\begin{array}{l}\text { The calculated values } \\
\text { are dependent on the } \\
\text { size of the interval } \\
\left\lfloor\max _{i} a_{i j} ; \min _{i} a_{i j}\right\rfloor\end{array}$ \\
\hline 3 & $\begin{array}{l}\text { Jüttler's-Körth’s } \\
(1969) \\
\text { normalization }\end{array}$ & $b_{i j}=1-\mid \frac{\max _{i} a_{i j}-a_{i j}}{\max _{i} a_{i j}}$ & $b_{i j}=1-\mid \frac{\min _{i} a_{i j}-a_{i j}}{\min _{i} a_{i j}}$ & $\begin{array}{l}\text { The application of } \\
\text { this type of } \\
\text { normalization is } \\
\text { limited to the interval } \\
{[0 ; 1] .}\end{array}$ \\
\hline 4 & $\begin{array}{l}\text { Peldschus et al. } \\
\text { (1983) non-linear } \\
\text { (NL) } \\
\text { normalization }\end{array}$ & $b_{i j}=\left(\frac{a_{i j}}{\max _{i} a_{i j}}\right)^{2}$ & $b_{i j}=\left(\frac{\min _{i} a_{i j}}{a_{i j}}\right)^{3}$ & $\begin{array}{l}\text { The values are } \\
\text { diminished more than } \\
\text { when using other } \\
\text { methods }\end{array}$ \\
\hline 5 & $\begin{array}{l}\text { New } \\
\text { Logarithmic } \\
\text { (LN) } \\
\text { normalization }\end{array}$ & $b_{i j}=\frac{\ln \left(a_{i j}\right)}{\ln \left(\prod_{i=1}^{n} a_{i j}\right)}$ & $b_{i j}=\frac{1-\frac{\ln \left(a_{i j}\right)}{\ln \left(\prod_{i=1}^{n} a_{i j}\right)}}{n-1}$ & $\begin{array}{l}\text { The sum of } \\
\text { normalized criterion } \\
\text { values is always equal } \\
\text { to } 1 .\end{array}$ \\
\hline
\end{tabular}


Wald's rule (WA): This method is used to search for the best of the worst solutions (Wald, 1945). The decision-maker acts according to the worst situation occurring (a pessimistic attitude):

$$
S^{*}=\left\{S_{i} / S_{i} \in S \cap \max _{i} \min _{j} b_{i j}\right\}
$$

Savage criterion (SA): The aim is to minimize the loss of appropriateness, which is the difference between the greatest and the achieved benefit (Savage, 1951):

$$
S^{*}=\left\{S_{i} / S_{i} \in S \cap \min _{i} \max _{j} c_{i j} \cap c_{i j}=\left(\max _{r} a_{r s}\right)-a_{r s}\right\},
$$

where $r=\overline{1, m}$ and $s=\overline{1, n}$. A disadvantage of the method is in the presence of nonoptimal strategies affecting the solution.

Hurwicz's rule (HU): An optimal strategy is based on the best and the worst results (Hurwicz, 1951). These values, calculated from the row's minimum and row's maximum, are integrated into a weighted average using optimism parameters:

$$
S^{*}=\left\{S_{i} / S_{i} \in S \cap \max _{i} h_{i} \cap h_{i}=\lambda \max _{j} b_{i j}+(1-\lambda) \min _{j} b_{i j} \cap 0 \leqslant \lambda \leqslant 1\right\} .
$$

The value $\lambda=1$ gives the most pessimistic solution (Wald's rule). For the value of $\lambda=0$ only the maximum (the greatest risk) values are considered.

Laplace's rule (LA): The solution is calculated under the condition that all probabilities for the strategies of the opponent are equal (Bernoulli, 1738):

$$
S^{*}=\left\{S_{i} / S_{i} \in S \cap \max _{i}\left(1 / n \sum_{i=1}^{n} b_{i j}\right)\right\} .
$$

Bayes's rule (BA): Given the probabilities for the strategies of the opponent, the maximum for the expected value can be used (Arrow et al., 1949):

$$
S^{*}=\left\{S_{i} / S_{i} \cap \max _{i}\left(\sum_{j=1}^{n} q_{j} b_{i j}\right) \cap \sum_{j=1}^{n} q_{j}=1\right\} .
$$

Hodges-Lehmann rule (HL): According to this rule, the confidence in the knowledge of the probabilities of the opponent's strategies can be expressed by the parameter $\lambda$ (Hodges and Lehmann, 1952):

$$
S^{*}=\left\{S_{i} / S_{i} \in S \cap \max _{i}\left[\lambda \sum_{j=1}^{n} q_{j} b_{i j}+(1-\lambda) \min _{j} b_{i j}\right] \cap 0 \leqslant \lambda \leqslant 1\right\},
$$

where $\lambda=0$ (no confidence) gives the solution according to Wald's rule, while $\lambda=1$ (great confidence) gives the solution according to Bayes's rule. 


\section{Normalization Test in the Case of Various Data Intervals}

In order to test the described new normalization method, we will consider the normalization of test matrices. The alternatives of the initial data for normalization are designed according to various distribution laws:

$$
\begin{aligned}
& x_{1 i}=0+i ; \quad x_{2 i}=10+i ; \quad x_{3 i}=100+i ; \\
& x_{4 i}=1000+i ; \quad x_{5 i}=10^{(i-1)} ; \quad x_{6 i}=0.001 \cdot 10^{i}, \quad \text { where } i=\overline{1,10} .
\end{aligned}
$$

The values of the initial data are changed depending on particular intervals. The assumption is made that all criteria are maximized. A comparison of the test results is given in Table 2.

Based on the comparison of normalization results, we can make the following conclusion: the application of a new logarithmic normalization method yields the values of the normalized matrix elements approaching the average values obtained in other normalization methods. In some cases, the obtained values are approximately equivalent to the values of linear normalization.

Table 2

Comparison of the test results of matrix logarithmic normalization

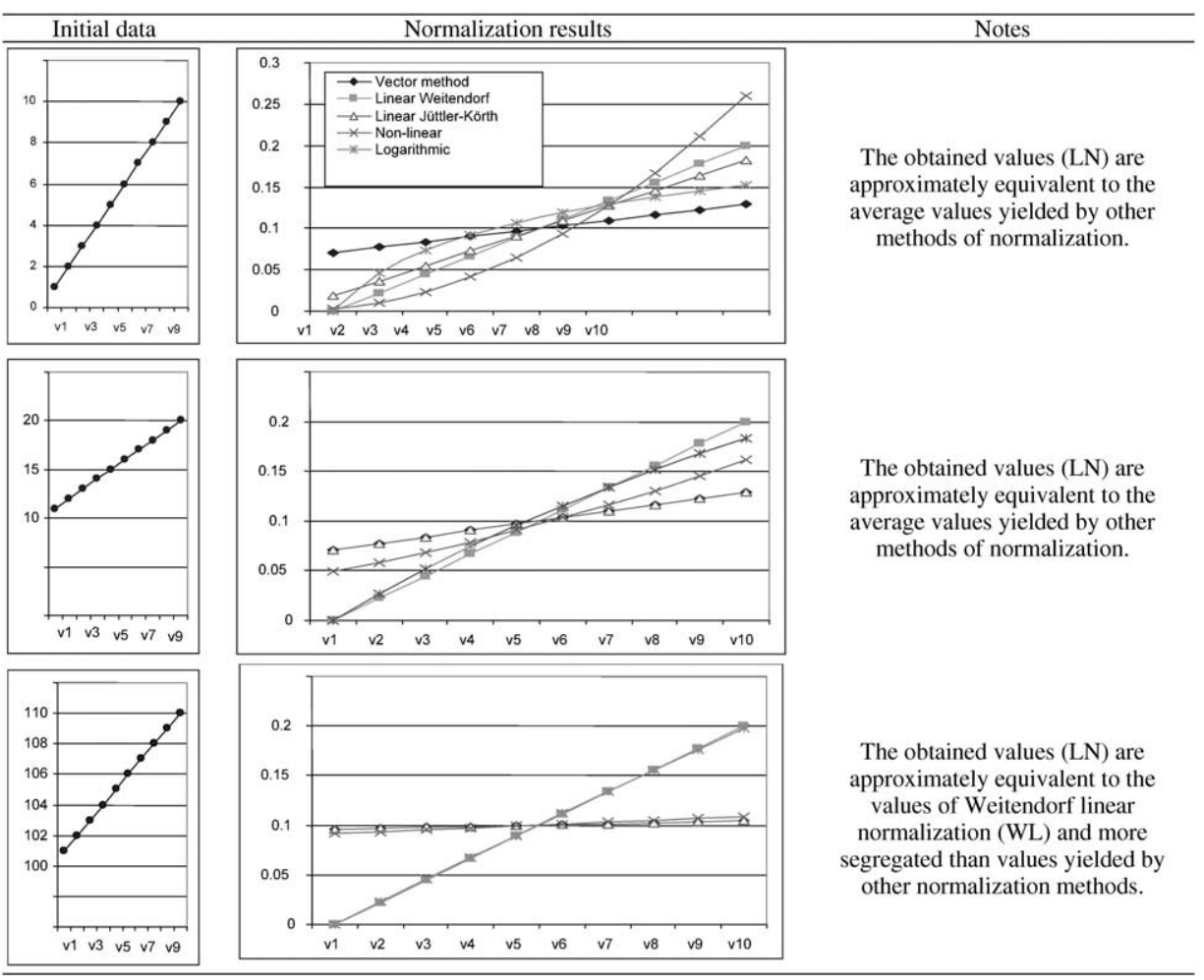


Table 2 (continued)

Comparison of the test results of logarithmic normalization presented in the matrix

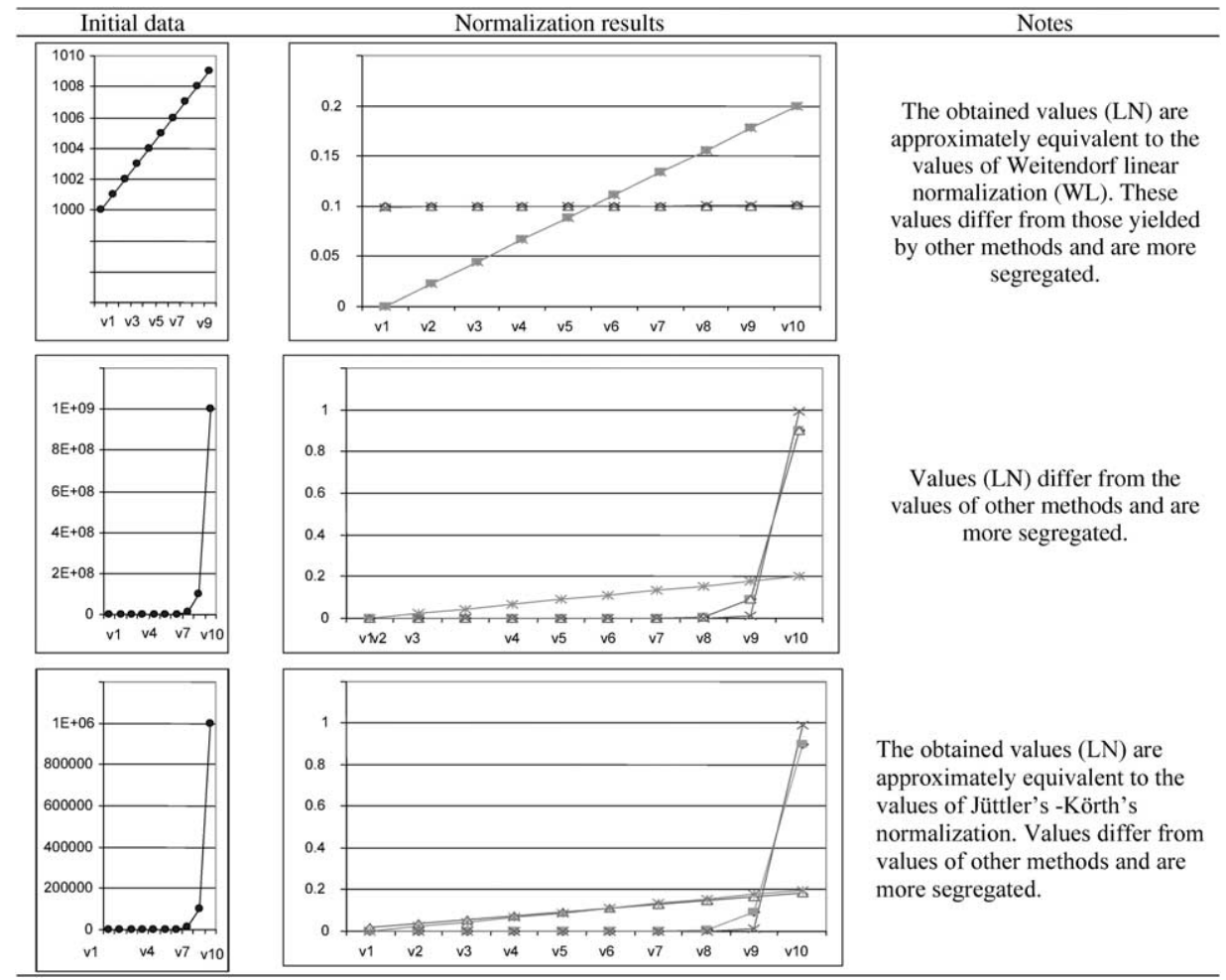

\section{A Case Study of Alternatives' Evaluation Using Various Solution Methods and Normalization Techniques}

To illustrate the application of the described methods, the problem of the selection of a rational option of the external finishing for cast-in-place buildings will be considered (Zavadskas et al., 1994). To select a rational alternative of external wall finishing in castin-place buildings, a survey of five technological alternatives was conducted. A13-storey block-of flats in Justiniskes, a suburb of Vilnius, served as an example of analysis. The initial data for evaluation of the alternatives are given in Table 3 . The first alternative deals with developing a relief surface of concrete by assembling the structures on formwork when concrete is placed in metal forms. The second alternative deals with the decoration of facades by open work structural elements of $1.0 \times 0.5$ m made of gypsum concrete slabs. The third alternative presents facing of ceramic tiles. The fourth alternative deals with painting of the balconies with a long-lasting paint. The fifth alternative deals with painting of the whole facade with a long-lasting paint. The evaluation of the alternatives was based on the following four attributes: 1) costs $x_{1}$, thousand \$; 2) labour input $x_{2}$, man-days; 3), 4) the criteria 3 and 4 (durability $x_{3}$ and aesthetics $x_{4}$ ) were evaluated in points by 28 experts. The criteria weights were determined by the method of pairwise 
Table 3

The initial data for assessing project alternatives and results of decision matrix normalization

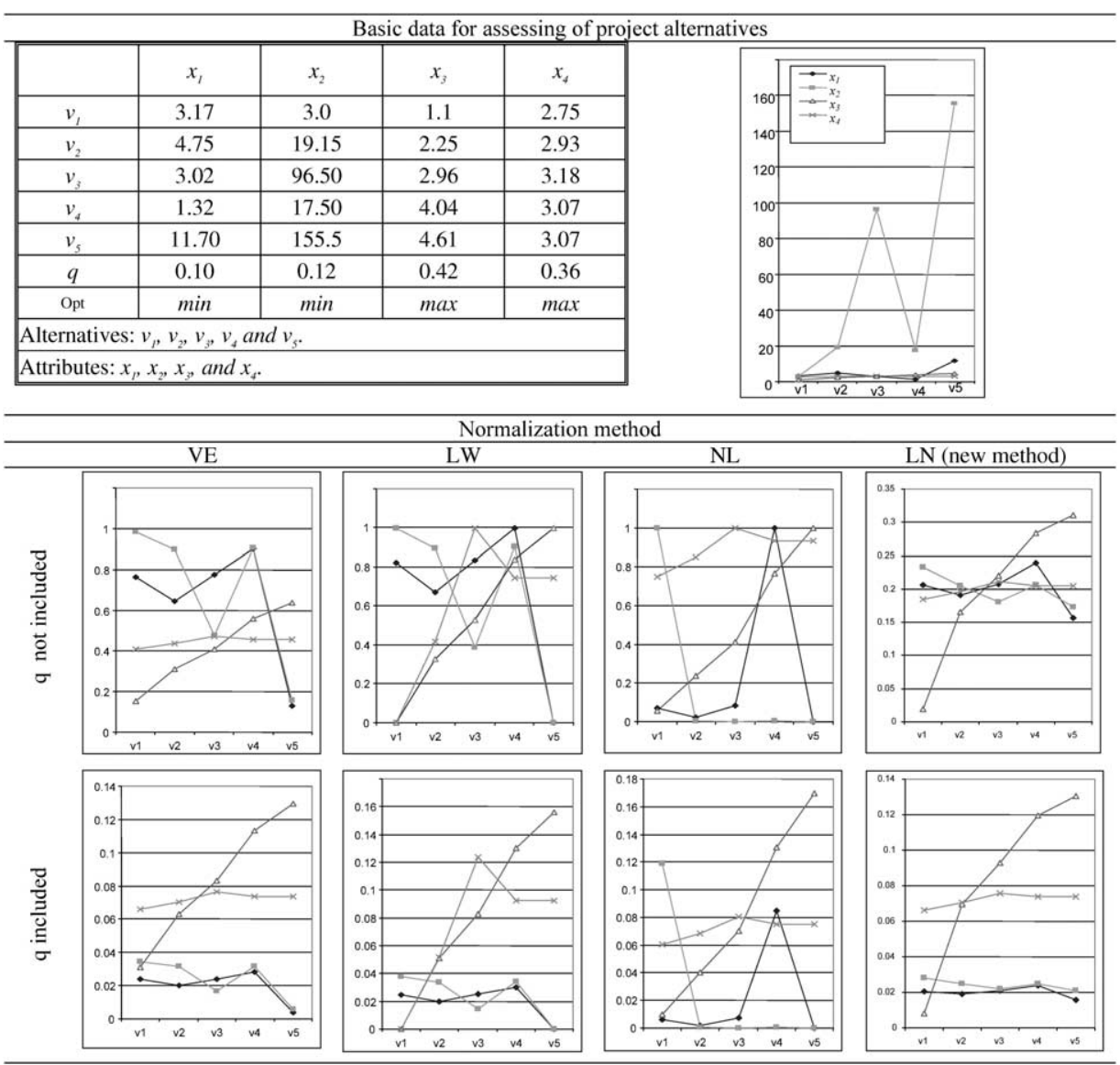

comparison based on the estimates of 28 experts. The obtained weight vector of attributes was $q=(0.10,0.12,0.42,0.36)$.

In the present investigation, the vector, linear, non-linear and new logarithmic methods of initial decision-making matrix normalization were used. A number of different problem solution methods, such as Wald's rule, Savage criterion, Hurwicz's rule, also Laplace's rule, Bayes's rule, Hodges-Lehmann-rule, were also applied. Tables 4 and 5 provide the solution results and graphical representation of their comparative analysis. The use of logarithmic normalization improves the quality of decision matrix normalization in solving economic and organizational problems.

When the criteria weights are taken into account, the priority order of the alternatives is presented as $v_{4} \succ v_{3} \succ v_{5} \succ v_{2} \succ v_{1}$ (implying that the "fourth" alternative is better than the "third" one, the "third" alternative is better than the "fifth" one, the "fifth" alternative is better than the "second" one and the "second" alternative is better than the "first" one). A similar set $v_{4} \succ v_{5} \succ v_{3} \succ v_{2} \succ v_{1}$ is obtained when the criteria weights are not taken into account in the process of alternative assessment. 
Table 4

Ranking of the alternatives

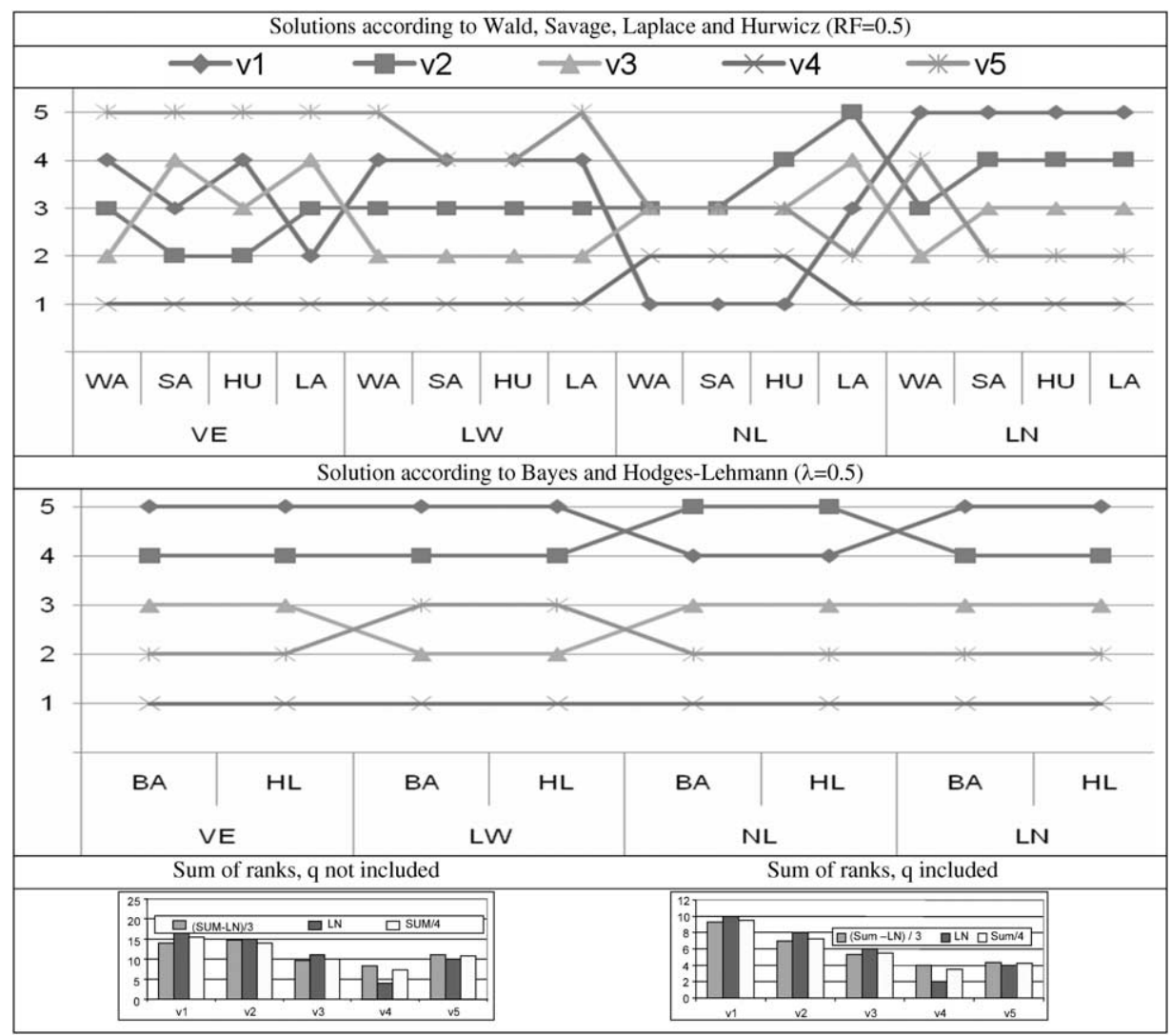

Table 5

Ranks of the project alternatives. Solutions according to Wald, Savage, Laplace and Hurwicz $(\mathrm{RF}=0.5)$, Bayes and Hodges-Lehmann $(\lambda=0.5)$

\begin{tabular}{|c|c|c|c|c|c|c|}
\hline \multirow{3}{*}{ NM } & \multicolumn{6}{|c|}{ Ranks of alternatives } \\
\hline & \multicolumn{4}{|c|}{$q$ not included } & \multicolumn{2}{|c|}{$q$ included } \\
\hline & WA & SA & $\mathrm{HU}$ & LA & $\mathrm{BA}$ & HL \\
\hline VE & $4 \succ 3 \succ 2 \succ 1 \succ 5$ & $4 \succ 2 \succ 1 \succ 3 \succ 5$ & $4 \succ 2 \succ 3 \succ 1 \succ 5$ & $4 \succ 1 \succ 2 \succ 3 \succ 5$ & $4 \succ 5 \succ 3 \succ 2 \succ 1$ & $4 \succ 5 \succ 3 \succ 2 \succ 1$ \\
\hline LW & $4 \succ 3 \succ 2 \succ 1 \succ 5$ & $4 \succ 3 \succ 2 \succ 1=5$ & $4 \succ 3 \succ 2 \succ 1=5$ & $4 \succ 3 \succ 2 \succ 1 \succ 5$ & $5 \succ 4 \succ 2 \succ 1 \succ 3$ & $5 \succ 4 \succ 2 \succ 1 \succ 3$ \\
\hline NL & $1 \succ 4 \succ 2=3=5$ & $1 \succ 4 \succ 2=3=5$ & $1 \succ 3=4 \succ 5 \succ 2$ & $4 \succ 5 \succ 1 \succ 3 \succ 2$ & $4 \succ 5 \succ 3 \succ 1 \succ 2$ & $4 \succ 5 \succ 3 \succ 1 \succ 2$ \\
\hline $\mathrm{LN}$ & $4 \succ 3 \succ 2 \succ 5 \succ 1$ & $4 \succ 5 \succ 3 \succ 2 \succ 1$ & $4 \succ 5 \succ 3 \succ 2 \succ 1$ & $4 \succ 5 \succ 3 \succ 2 \succ 1$ & $4 \succ 5 \succ 3 \succ 2 \succ 1$ & $4 \succ 5 \succ 3 \succ 2 \succ 1$ \\
\hline
\end{tabular}


The results of problem solution are more stable. For example, when the weights of the criteria are included in calculation, various methods and logarithmic normalization used in solving the problem determine the alternative 4 as the most effective, while other normalization methods give different results. If weights of the criteria are not included in the evaluation process, the most effective option according to the logarithmic normalization (e.g., linear normalization) is the alternative 4 , while other normalization methods describe other alternatives as optimal.

According to the results obtained in the analysis, the most effective fourth alternative was implemented.

\section{Conclusions}

It is hardly possible to evaluate the effect of various methods of normalization of a decision-making matrix on the numerical results obtained. These problems can be solved by applying the program LEVI 3.1 .

Some modules of the program LEVI 3.1 can be used for creating decision-making systems.

Logarithmic normalization of a decision-making matrix has been used for the first time. Logarithmic normalization of a decision-making matrix yields more stable results in solving multi-criteria decision problems.

The calculations show that logarithmic normalization may be used in the cases when the values of the criteria differ considerably.

The logarithmic normalization method used in solving the problems segregates normalized values more effectively than other methods.

A comparison of results obtained by different solution methods is needed because it is not always possible to apply the games theory equilibrium to economics, engineering and management.

\section{References}

Antuchevičienė, J., Z. Turskis, E.K. Zavadskas (2006). Modelling renewal of construction objects applying methods of the game theory. Technological and Economic Development of Economy, 12(4), 263-268.

Arrow, K.J., D. Blackwell and M.A. Girshick (1949). Bayes and minimax solutions of sequential decision problems. Econometrica, 17, 213-243.

Bernoulli, D. (1738). Specimen theoriae novas de mesure sortis. Comentarii Academiae Scientarium Inperialis Petropolitanae, 5, 1750-192. Translated by L. Sommer (1954). Exposition of a new theory on the measurement of risk. Econometrica, 22, 23-36.

Brauers, W.K. (2007a). What is meant by normalization in decision making? International Journal of Management and Decision Making, 8(5-6), 445-460.

Brauers, W.K. (2007b). Normalisation in multiobjective optimization: a general overview. International Journal of Management and Decision Making, 8(5-6), 461-474.

Brauers, W.K., M.R. Ginevicius, E.K. Zavadskas and J. Antucheviciene (2007). The European Union in a transition economy. Transformations in Business and Economics, 6(2), 21-37.

Brauers, W.K., and E.K. Zavadskas (2006). The MOORA method and its application to privatization in a transition economy. Control and Cybernetics, 35(2), 443-468. 
Cloquell, V.A., and C. Santamarina (2001). A new procedure for the numerical values normalization in multicriteria decision techniques. In MCDA 54th Meeting in Durbuy. Universidad Politécnica de Valencia, Valencia. pp. $1-10$.

Dejus, T. (2002). The model of determining the sensitivity of elements of multiple criteria evaluation methods. Journal of Civil Engineering and Management, 8(4), 263-286.

Ginevicius, R., and V. Podvezko (2007). Some problems of evaluating multicriteria decision methods. International Journal of Management and Decision Making, 8(5-6), 527-539.

Hodges, J.L., and E.L. Lehmann (1952). The use of previous experience in reaching statistical decision. Annals of Mathematics Studies, 23, 396-407.

Hovanov, N. (1996). Analysis and Synthesis of Parameters under Information Deficiency. St. Petersburg University Press, St. Petersburg.

Hwang, C.L., and K.P. Yoon (1981). Multiple Attribute Decision Making - Methods and Applications. SpringerVerlag, New York.

Hurwicz, L. (1951). Optimality criteria for decision making under ignorance. cowles commission paper. Statistics, 370, 45-52.

Jüttler, H. (1966). Untersuchungen zur Fragen der Operations aforschung und ihrer Anwendungsmöglichkeiten auf ökonomische Problemstellungen unter besonderer Berücksichtigung der Spieltheorie. Dissertation A an der Wirtschaftswissenschaftlichen Fakultät der Humboldt-Universität, Berlin.

Kaklauskas, A., E.K. Zavadskas, A. Banaitis and G. Šatkauskas (2007). Defining the utility and market value of real estate: a multiple criteria approach. International Journal of Strategic Property Management, 11(2), $107-120$.

Kalibatas, D., M. Krutinis and M. Viteikienè (2007). Multi-objective evaluation of microclimate in dwelling. Technological and Economic Development of Economy, 13(1), 24-31.

Körth, H. (1969). Zur Berücksichtigung mehrer Zielfunktionen bei der Optimierung von Produktionsplanen. Mathematik und Wirtschaft, 6, 184-201.

Migilinskas, D. (2003). The influence of normalization methods selection in construction including game theory adaptation. Technological and Economic Development of Economy, 9(2), 73-79 (in Lithuanian).

Migilinskas, D., and L. Ustinovichius (2007). Normalisation in the selection of construction alternatives. International Journal of Management and Decision Making, 8(5-6), 623-639.

Neumann von, J., and O. Morgenstern (1943). Theory of Games and Economic Behavior. Princeton University Press.

Noorul Haq, A., and G. Kannan (2007). A Hybrid normalised multi criteria decision making for the vendor selection in a supply chain model. International Journal of Management and Decision Making, 8(5-6), 601-622.

Peldschus, F. (1986). Zur Anwendung der Theorie der Spiele für Aufgaben der Bautechnologie. Diss. B. Technologie. Diss. B. Technische Hochschule Leipzig.

Peldschus, F. (2001). Sensibilitätsuntersuchungen zu Methoden der merhkriteriellen Entscheidungen. Journal of Civil Engineering and Management (Statyba), 7(4), 276-281.

Peldschus, F. (2007). The effectiveness of assessment in multiple criteria decisions. International Journal of Management and Decision Making, 8(5-6), 519-526.

Peldschus, F., D. Messing, E.K. Zavadskas, L. Ustinovichius and Z. Turskis (2002). LEVI 3.0 - multiple criteria evaluation program under uncertainty. Technological and Economic Development of Economy, 8(1), 3-12.

Peldschus, F., E. Vaigauskas and E.K. Zavadskas (1983). Technologische Entscheidungen bei der Berücksichtigung mehrerer Ziehle. Bauplanung-Bautechnik, 37(4), 173-175.

Peldschus, F., and E.K. Zavadskas (1997). Matrix Games in Building Technology and Management. Technika, Vilnius (in Lithuanian).

Savage, L.J. (1951). The theory of statistical decision. Journal of the American Statistical Association, 46, 55-57.

Stopp, F. (1975). Variantenvergleich durch Matrixspiele. Wissenschaftliche Zeitschrift der Hochschule für Bauwesen Leipzig, 2, 117.

Turskis, Z., E.K. Zavadskas and J. Zagorskas (2006). Sustainable city compactness evaluation of the basis of GIS and Bayes rule. International Journal of Strategic Property Management, 10(3), 185-207.

Ustinovichius, L. (2001). Determining integrated Criteria significance of attributes. Journal of Civil Engineering and Management (Statyba), 7(4), 321-326. 
Ustinovichius, L. (2004). Determination of efficiency of investments in construction. International Journal of Strategic Property Management, 8(1), 25-43.

Ustinovichius, L. (2007). Methods of determining objective, subjective and integrated weights of attributes. International Journal of Management and Decision Making, 8(5-6), 540-554.

Ustinovichius, L., and E.K. Zavadskas (2004). Assessment of investment profitability in construction from the technological perspective. Technika, Vilnius (in Lithuanian).

Ustinovichius, L., E.K. Zavadskas and V. Podvezko (2007). Application of a quantitative multiple criteria decision making (MCDM-1) approach to the analysis of investment in construction. Control and Cybernetics, 36(1), 251-268.

Van Delft, A., P. Nijkamp (1977). Multi-Criteria Analysis and Regional Decision-Making. M. Nijhoft, Leiden, N1.

Vaidogas E.R., and E.K. Zavadskas (2007). Introducing reliability measures into multi-criteria decision-making. International Journal of Management and Decision Making, 8(5-6), 475-496.

Vaidogas E.R., E.K. Zavadskas and Z. Turskis (2007). Reliability measures in multicriteria decision making as applied to engineering projects. International Journal of Management and Decision Making, 8(5-6), 497518.

Viteikiene, M. (2006). Sustainable residential areas evaluation. Technological and Economic Development of Economy, 12(2), 152-160.

Viteikiene, M., and E.K. Zavadskas (2007). Evaluating the sustainability of Vilnius city residential areas. Journal of Civil Engineering and Management, 13(2), 149-155.

Wald, A. (1945). Statistical decisions functions which minimise the maximum risk. Annals of Mathematics, 46 , 265-280.

Weitendorf, D. (1976). Beitrag zur Optimierung der räumlichen Struktur eines Gebäudes. Dissertation A, Hochschule für Architektur und Bauwesen. Weimar.

Zagorskas, J., and Z. Turskis (2006). Multi-attribute model for estimation of retail centres influence on the city structure. Kaunas city case study. Technological and Economic Development of Economy, 12(4), 347-352.

Zavadskas, E.K. (1987). Multiple criteria evaluation of technological decisions of construction. Dissertation of Dr. Sc. Moscow Civil Engineering Institute, Moscow (in Russian).

Zavadskas, E.K., and A. Kaklauskas (2007). Mehrzielselection für Entscheidungen im Bauwesen. Fraunhofer IRB Verlag.

Zavadskas, E.K., A. Kaklauskas, F. Peldschus and Z. Turskis (2007a). Multi-attribute assessment of road design solutions by using the COPRAS method. The Baltic Journal of Road and Bridge Engineering, 2(4), 195-203.

Zavadskas, E.K., F. Peldschus and A. Kaklauskas (1994). Multiple Criteria Evaluation of Projects in Construction. Technika, Vilnius.

Zavadskas, E.K., F. Peldschus and L. Ustinovichius (2003). Development of software for multiple criteria evaluation. Informatica, 14(2), 259-272.

Zavadskas, E.K., F. Peldschus, L. Ustinovichius and Z. Turskis (2004). Game Theory in Building Technology and Management. Technika, Vilnius (in Lithuanian).

Zavadskas, E.K., Z. Turskis, T. Dejus and M. Viteikiene (2007b). Sensitivity analysis of a simple additive weight method. International Journal of Management and Decision Making, 8(5-6), 555-574.

Zavadskas, E.K., L. Ustinovichius, Z. Turskis, F. Peldschus and D. Messing (2002). LEVI 3.0 - Multiple criteria evaluation program for construction solutions. Journal of Civil Engineering and Management, 8(3), 184191.

Zavadskas, E.K., A. Zakarevicius and J. Antucheviciene (2006). Evaluation of ranking accuracy in multi-criteria decisions. Informatica, 17(4), 601-617. 
E.K. Zavadskas is a principal vice-rector of Vilnius Gediminas Technical University and a head of the Dept. of Construction Technology and Management at Vilnius Gediminas Technical University, Vilnius, Lithuania. He has a PhD in building structures (1973) and Dr Sc (1987) in building technology and management. He is a member of the Lithuanian and several foreign Academies of Sciences. He is doctore honoris causa at Poznan, SaintPetersburg, Kiev. He is a member of international organisations and has been a member of steering and programme committees at many international conferences. E.K. Zavadskas is a member of editorial boards of several research journals. He is author and co-author of more than 300 papers and a number of monographs in Lithuanian, English, German and Russian. Research interests are: building technology and management, decision-making theory, automation in design and decision support systems.

Z. Turskis $(\mathrm{PhD})$ is a senior research fellow of Construction Technology and Management Laboratory of Vilnius Gediminas Technical University, Lithuania. His research interests include building technology and management, decision-making theory, computeraided automation in design and expert systems. He is the author of 20 scientific papers.

\title{
Naujasis logaritminis normalizavimo metodas, naudojamas lošimu teorijoje
}

\author{
Edmundas Kazimieras ZAVADSKAS, Zenonas TURSKIS
}

Daugiakriterinis sprendimu prièmimas yra naudojamas daugelyje visuomenès veiklos sričių. Alternatyva daugiakriteriniame vertinime dažniausiai yra apibrěziama kiekybiniais ir kokybiniais kriterijais, kurie turi skirtingus matavimo vienetus. Normalizuojant šiuos kriterijus siekiama jų suvienodinimo, kad būtụ galima palyginti kriterijų reikšmes. Nors normalizavimas ne visada reikalingas, jis gali būti labai svarbus kai kuriais atvejais, pavyzdžiui, lošimų teorijoje. Naujai sukurtoje programoje LEVI 3.1 yra naudojami tokie normalizavimo metodai: vektorinis, linijinis, nelinijinis ir naujasis logaritminis. Logaritminis normalizavimas niekada nebuvo panaudotas. Šiame tyrime pagrindinis demesys yra skiriamas logaritminio metodo, naudojamo sprendimu prièmimo matricos normalizavimui, aprašymui. 